\title{
Job opportunities and school-to-work transitions in occupational labour markets. Are occupational change and unskilled employment after vocational education interrelated?
}

Helen Buchs ${ }^{1 *}$ and Laura Alexandra Helbling ${ }^{2}$

${ }^{*}$ Correspondence:

buchs@soziologie.uzh.ch

1 Institute of Sociology,

University of Zürich,

Andreasstrasse 15,

8050 Zurich, Switzerland

Full list of author information

is available at the end of the

article

\begin{abstract}
Background: This study links TREE panel data surveying school-to-work transitions in Switzerland with unique job advertising data from the Swiss Job Market Monitor that mirrors individual job opportunities. We investigate: (i) whether occupational change and unskilled entry level employment are two related transition outcomes among graduates from initial vocational education and training (IVET) in the occupational labour market of Switzerland. Our analysis further focuses on (ii) the impact of a low number of occupation-specific job opportunities on the risk of such a combined horizontal and vertical job-education mismatch, and (iii) the extent to which overall labour demand facilitates occupational changes to skilled employment.
\end{abstract}

Methods: We make use of bivariate probit analysis to investigate occupational change and unskilled entry employment among IVET graduates as interrelated transition outcomes.

Results: The empirical results suggest that occupational change and unskilled entry employment are two interrelated transition outcomes among IVET graduates in Switzerland. The results further support our hypothesis that a low number of occupation-specific job vacancies at labour market entry increase the risk of simultaneously experiencing both forms of job-education mismatches for IVET graduates. High overall labour demand enables occupational changes to skilled employment.

Conclusions: We conclude that for an integration of IVET graduates into occupationally and educationally matching positions it is crucial that the IVET programmes offered match labour demand on an occupational basis.

Keywords: Initial vocational education and training, School-to-work transition, Jobeducation mismatch, Occupational change, Unskilled employment, Vacancies, Job opportunities, Labour demand

\section{Background}

Introduction

Well-established vocational education and training systems (VET) have become widely recognised as facilitating smooth school-to-work transitions (Buchmann 2011). One main reason for successful labour market entry can be found in institutionalised

(c) The Author(s) 2016. This article is distributed under the terms of the Creative Commons Attribution 4.0 International License (http://creativecommons.org/licenses/by/4.0/), which permits unrestricted use, distribution, and reproduction in any medium, provided you give appropriate credit to the original author(s) and the source, provide a link to the Creative Commons license, and indicate if changes were made. 
pathways from specific vocational programmes to the occupations trained for. However, what happens if qualified job opportunities in the occupational field in which young adults have trained are scarce at the time of graduation? Facing low occupation-specific demand, IVET (initial vocational education and training) graduates may have to switch occupations or accept unskilled employment (meaning employment not requiring an IVET diploma or other educational qualifications) to avoid possible unemployment. In doing so, they may, however, lose some of the skills they have acquired during training. On taking up unskilled employment they stand to lose their investment in a qualifying education at upper-secondary level and on changing occupations they may not be able to transfer occupation-specific skills gained during IVET to the labour market (Mueller and Schweri 2015). Moreover, lacking the corresponding occupation-specific certificate that allows access to skilled employment in the new occupation, young people that switch occupations immediately after IVET graduation may have to accept unskilled jobs that do not require any certifying education. This may happen especially when overall demand is low as employers in a situation of plentiful choice might not be disposed to hiring candidates with non-matching occupational credentials. Hence, in occupational labour markets occupational change and unskilled entry employment are likely to be related transition outcomes.

Understanding how occupational changes and unskilled employment at entry to an occupational labour market could be interrelated is crucial for our knowledge of the effects of IVET on young adults' labour market prospects and hence on social stratification. An occupational change concurring with unskilled employment may hamper IVET graduates' career advancement and future employment prospects. Skill underutilisation and work experience in unskilled jobs may be a negative signal at future hiring (see Pedulla 2016; Salvisberg and Sacchi 2013). Furthermore, the human capital accumulated on-the-job in unskilled positions may be of a lower "market-value" than that accumulated in skilled positions (Mincer 1974). Therefore, the young people that only gain work experience in unskilled jobs are probably less competitive with regard to future employment prospects than those who can prove work experience in skilled jobs. Thus, unskilled employment at entrance to the labour market may hinder subsequent upward mobility into skilled jobs. In this vein, research has demonstrated that unskilled employment at entrance to an occupationally segmented labour market tends to persist throughout individual careers (Baert et al. 2013; Pollmann-Schult and Büchel 2002; Scherer 2004). In Switzerland this entrapment effect is especially strong as the country's training system is very specific (Verhaest and Velden 2012). Similarly, entering an occupational labour market during economic recessions, when overall labour demand is low and graduates risk of having to accept unskilled employment is high, has been shown to crucially hamper future occupational and social positioning (Blossfeld 1985; Vandenberghe 2010; Verhaest and Velden 2012).

Against this background, the present study aims to assess how far occupational change and unskilled employment at entry to an occupational labour market-the Swiss labour market-are interrelated. Furthermore, this study seeks to shed light on the role that occupation-specific job opportunities available to IVET graduates play in increasing or decreasing the risk of a twofold job-education mismatch at labour market entry. Finally, 
this study looks at how far a high overall labour demand favours occupational changes into skilled employment.

In answering these questions, we aim to shed light on the relation between occupational change and unskilled employment at entrance to an occupational labour market and hence on how occupational change may represent a pattern of an unsuccessful transition. Moreover, by closely looking at the amount and composition of vacancies, we highlight the important role the demand side plays for the transition to the labour market. In this way, this is one of the first studies about the transition from IVET to the labour market to integrate occupation-specific labour demand at the micro level, measuring the individual job opportunities of young people (with the exceptions of Buchs and Müller 2016; Buchs et al. 2015). Given the institutionalised pathways from particular IVET programmes to corresponding occupations, this refined consideration of the demand side should allow for a better understanding of job-education mismatches at labour market entry.

This research paper is structured as follows: we first shed light on the transition from vocational education to an occupational labour market and describe IVET in Switzerland. We then outline some theoretical considerations of job-education mismatches among IVET graduates and thereby the role of the strength of labour demand in the occupation for which the young people were trained and in the overall labour market. We then move on to describe the data and methods used before we report our empirical findings. Finally, the results are discussed and conclusions drawn.

\section{IVET and employment entry}

Vocational education and training is the basis for occupationally segmented labour markets and it therefore structures pathways to employment along vocational lines. Work experience, occupational specificity and a high standardisation can be detected as the main factors preparing the ground for labour market entrance. In the following paragraphs we will use the example of Switzerland to describe the role of these factors for the connection between IVET and employment. Switzerland provides an excellent case study as IVET is its predominant form of upper secondary education and the labour market has been shown to be strongly segmented along vocational lines (Kriesi et al. 2010).

Standard IVET programmes in Switzerland take 3 or 4 years and completion is certified with a federal IVET diploma (Eidgenössisches Fähigkeitszeugnis). ${ }^{1}$ Concurrently, or following on from IVET at upper-secondary level, young people have the option of obtaining a federal vocational baccalaureate (Berufsmaturität), qualifying them to enrol in the universities of applied sciences (SERI 2015; Stalder and Nägele 2011). Close to 90\% of IVET students engage in dual programmes where company-based training and school-based learning are combined (apprenticeship) (see e.g. SERI 2015; Wolter and Ryan 2011). However, this rate differs by region. Since young people pursuing dual IVET gain some initial work experience, induction costs for prospective employers are fairly

${ }^{1}$ A 2-year VET programme option also exists that allows for qualifications for certain occupational profiles awarded with a (basic) federal IVET certificate. This is also an option for young people who may not easily meet the demands of standard VET programmes. Following completion of a 2-year programme, graduates may then enrol in a 3-4 year standard VET programme (see SERI 2015; SKBF 2014; Stalder and Nägele 2011). 
low and graduates from dual IVET can compete more easily for jobs at labour market entry with older job seekers who have a longer work history.

In addition, vocational education in Switzerland is highly occupation-specific. Around 230 training occupations exist and, apart from some general skills, each provides predominantly occupation-specific competences and skills. However, training programmes differ greatly in occupational specificity. In any case, occupational skills in combination with practical experience prepare IVET graduates for entering employment in the corresponding occupation, but broad training might allow for greater occupational mobility than specific trainings as the provided skills are more general and thus the loss of occupation-specific skills when switching occupations might be smaller (Eggenberger et al. 2015).

Furthermore, the content of training and the standards in Switzerland are strongly employer-driven, so as to meet labour market demand for specific occupational skills. The VET system is tripartite being governed by the Confederation, the cantons, and the professional organisations (see SERI 2015; SKBF 2014), thus ensuring national standardisation of vocational programmes. Standardisation of vocational training programmes leads to reliable signalling effects of occupation-specific credentials for occupation-specific knowledge and skills. Employers therefore mainly recruit on the basis of IVET certificates. Accordingly, occupational credentials play by far the biggest role in job opportunities in the Swiss occupational labour market (Kriesi et al. 2010) and they establish a pathway from a specific training programme to employment in the corresponding occupational field.

In sum, the allocation of IVET graduates to jobs in the Swiss labour market follows an employment logic (see e.g. Gangl 2003; Iannelli and Raffe 2007) in which occupationspecific credentials qualify them for employment in the respective occupations. The strongly institutionalised pathway from school to work promotes smooth transitions into the labour market that are reflected in a high chance of finding skilled employment within the occupation for which they trained (see e.g. Buchs et al. 2015; OECD 2013).

\section{Mismatch and job opportunities in occupational labour markets}

The firm link between the vocational training programme and allocation to an occupational labour market implies that, in addition to overall demand, occupation-specific job opportunities are a decisive factor in job-education matches at labour market entry. In the following section we stress the approach of occupationally segmented labour markets to outline how occupational change and unskilled employment can be understood as related outcomes. We then discuss the role of the number of occupation-specific job opportunities and overall demand for occupational and educational mismatch at labour market entry.

Occupational labour markets are characterised by a division into a peripheral and an occupation-specific segment (Sengenberger 1978). The peripheral segment includes unskilled jobs for which employers do not require a post-obligatory educational credential. All job seekers can therefore access this segment, but this type of employment is characterised by unfavourable conditions (Sengenberger 1978; Sacchi et al. 2016). The occupational segment of the labour market consists of several occupation-specific subsegments. Each offers different conditions and employment prospects, which leads to 
the varying attractiveness of taking up a job in the corresponding sub-segment. However, access to occupational sub-segments is limited to job seekers holding the appropriate occupation-specific certificate (Blossfeld and Mayer 1988; Sengenberger 1978; Kriesi et al. 2010).

In occupationally segmented labour markets, young IVET graduates who cannot find a skilled job in the occupation for which they have been trained are not provided with an institutionalised pathway to skilled employment in other occupational sub-segments. Access to occupational segments that do not match the certificate obtained is constrained because occupational mobility would require the acquisition of an additional occupational certificate. Therefore, occupational changes at labour market entrance will direct young IVET graduates into the peripheral segment where no specific certificate is required to take up employment. Following this argument, we can expect occupational changes after IVET to be accompanied by engagement in unskilled employment.

Occupation-specific labour demand, according to the occupational segmentation of the labour market, can be seen to shape appropriate job opportunities for IVET graduates. Hence, the number of occupationally matching job vacancies may be a main driving factor behind occupational and educational mismatch at labour market entry (see also Buchs et al. 2015). According to labour queue theory (Thurow 1975), employers arrange applicants for a vacant position in an imaginary queue and consider the individual with the highest expected productivity. In occupational labour markets employers expect job seekers holding an IVET certificate that vocationally matches the vacant position to have higher productivity and they are usually prefer them over those holding a non-fitting certificate. In addition, work experience might be used as a further ranking criterion whereby labour market entrants with no work experience are probably ranked behind more experienced colleagues. If occupation-specific skill demand is high, despite the competition with more experienced job seekers IVET graduates can be expected to find a skilled job within the occupation for which they trained. However, in the event that qualified occupation-specific job opportunities are scarce, labour market entrants may be hindered in accessing skilled employment within the trained occupation because employers will prefer more experienced applicants. Young graduates in this situation will be confronted with the choice between an occupational change, which is probably related to engagement in unskilled work, or unemployment. As unemployment will usually be the least favourable outcome young graduates will try to switch occupations. The number of qualified occupation-specific vacancies at the time of completing IVET will thus be the overriding factor deciding whether or not IVET graduates can gain a foothold in occupationally matching and suitably skilled employment.

Drawing further on labour queue theory, we can argue that a high overall labour demand can negate the interrelation between occupational mismatch and unskilled employment. In situations of excess supply, employers can be more selective when recruiting. They then increase their requirements for taking up a certain job and will probably only recruit experienced individuals holding a specific occupational certificate. However, if employers have urgent personnel needs and are struggling to fill a vacancy they might reduce their requirements. Occupation-specific certificates, which, as we have argued, are usually regarded as a compulsory prerequisite, may in such situations not be a necessary prerequisite and any other vocational certificate might suffice. High 
overall labour demand may thus lead employers to accept young job applicants holding a non-matching occupational certificate in skilled positions. This may be to the advantage of young people who after completion of IVET switch to a new occupation. Further, high overall demand might pull IVET graduates into occupations for which they have not been trained. Existing research proposes that young people who completed a rather broad training programme may particularly profit from high overall labour demand, whereas those with very specific training might struggle more in accessing skilled jobs outside of the field of their IVET programme (Eggenberger et al. 2015). In short, upon graduation, the greater the number of vacant positions in the overall labour market, the more likely it is that graduates will be diverted to skilled employment outside of the occupation for which they trained.

\section{Hypotheses}

Based on this theoretical background, we derive the following three hypotheses to test:

Hypothesis 1 Occupational change upon graduation from IVET and unskilled employment are positively related transition outcomes.

Hypothesis 2 A low number of occupation-specific job opportunities at labour market entry drives job-education mismatching (unskilled employment accompanying occupational change) among IVET graduates.

Hypothesis 3 A high overall labour demand at labour market entry increases young people's chances to take up a skilled job outside of the occupational field for which they were trained.

\section{Data and methods \\ Data}

The analyses are based on the TREE database (Transition from Education to Employment). TREE is a longitudinal survey that follows the school-to-work transitions of about 6000 pupils who participated in PISA 2000 (Programme for International Student Assessment) and left compulsory schooling in the same year. These pupils were then followed annually from 2001 to 2007, with two additional surveys taking place in 2010 and 2014 (TREE 2013). Job-episode data is also available. Our analyses are restricted to young people who completed dual vocational education (apprenticeships) and entered the labour market between the years of 2003 and 2007. Young adults who began further education before entering the labour market are excluded. The main sample consists of 1277 individuals.

The analyses focus on the first significant job, which, in accordance with the literature, we define as the first job upon completion of IVET that has a minimum of 6 months' tenure and does not represent transitional employment such as practical training or an extended job search (see e.g. Blossfeld et al. 2015; Gebel 2010). This first job has to be reported in both the job episode-data and the yearly survey of TREE, such that information on the adequacy of the employment is available. A total of 284 IVET graduates in 
our sample did not engage in a first job that matched their occupational field of training (occupational change) and 287 entered the labour market via unskilled employment.

Accessible job opportunities at the time of graduation from IVET are measured at the micro level using job advertising data from the Swiss Job Market Monitor (SJMM) (http://www.stellenmarktmonitor.uzh.ch). The SJMM data contains annual representative random samples of around 4000 job advertisements from all parts of Switzerland, published across all relevant media channels, and covering all types of companies and occupations in Switzerland. The continuous monitoring spans the period from 1950 to 2016 (and onward) providing annual information on advertised jobs specified by location and occupation. Job advertisements allow for the adequate measurement of the personnel needs of employers in terms of specific occupational skills because job advertisements usually contain detailed information on job characteristics and the requirements that applicants must meet (Kriesi et al. 2010). Furthermore, the number of job advertisements approximately corresponds to excess demand because the more difficulties employers encounter in finding an appropriate employee, the more advertisements they publish for a vacant job. Therefore, the likelihood of a job being included in the dataset increases when a particular skill demand exceeds supply. Finally, linking this data to TREE data, we can measure job opportunities at the micro level and, unlike most existing research, we no longer need to rely on aggregate macro level data such as regional unemployment rates.

\section{Variables}

Our dependent variables are occupational change and unskilled employment. Occupational change is measured as a change from an IVET training occupation to a work occupation on the 2-digit level of occupation codes constructed by the Swiss Federal Statistical Office (39 categories). For this purpose, we first converted IVET training programmes into occupational codes. To ensure that similar jobs are not classified as occupational changes we also compared text information on training and jobs. Together with the use of rather broad occupational categories, this generates a valuable indicator that should not biased by differences in how specific skills are provided in training programmes or by how much occupations are differentiated within the classification system (for a similar approach see Buchs et al. 2015; Mueller and Schweri 2015). Unskilled employment is defined as employment not requiring a certificate. We identify unskilled employment if a young person states that his/her employment does not require completed training in any occupation and/or a completed education. ${ }^{2}$

The covariates on occupation-specific job opportunities and overall labour demand are constructed linking the job advertising data to individual transition data at the micro level. Occupation-specific job opportunities correspond to the number of qualified job advertisements available in the vocational field of the young person's training, the region of residence, and the year of graduation. Thus, qualified vacancies are those that address

\footnotetext{
2 To check for the robustness of this indicator we compared the occupational prestige (isei) of the jobs taken up across respondents reporting to be employed in skilled vs. unskilled work. On average, respondents classified as working in unskilled employment hold jobs of significantly lower occupational prestige compared to their peers that are classified as employed in skilled work. Furthermore, some respondents that report to be engaged in unskilled labour indicate that they work in fields that seem to generally require an upper-secondary education. Given that they may have misunderstood the question we recoded them as being engaged in skilled employment.
} 
job seekers holding a certificate at the upper secondary level. Given that IVET certificates, to a certain extent, allow for access to different occupations, we weight all job advertisements within a certain occupation by drawing on transition probabilities and add them to the occupation-specific vacancies. To this end, we use a training-employment matrix of 18 to 25 year old IVET graduates from the Swiss census date of the year $2000 .^{3}$ The smaller the transition probability from a training programme to a certain occupation, the less the vacancies in this occupation are weighted. Equally, living in a certain region allows for taking up jobs in different locations but individuals will favour short distances between residence and employment. We therefore further weight job advertisements according to driving distances between regional capitals (Kantonshauptstädte), with the lowest weights for vacancies furthest away from the district of residence. ${ }^{4}$

$$
O_{a x j}=\sum_{b=1}^{B}\left(w_{a b} * w_{x z} * n_{b z j}\right)
$$

$\mathrm{O}_{\mathrm{axj}}$ Number of vacancies in year $\mathrm{j}$ accessible from training a and location $\mathrm{x}$ weighted with individualised occupational and geographical transition probabilities.

$\mathrm{w}_{\mathrm{ab}}$ Transition probability from training a to occupation $\mathrm{b}$.

$\mathrm{w}_{\mathrm{xz}}$ Distance weight from location of residence $\mathrm{x}$ to location of job $\mathrm{z}$.

$\mathrm{n}_{\mathrm{bzj}}$ Number of vacancies advertised in year $\mathrm{j}$ in occupation $\mathrm{b}$ and location $\mathrm{z}$.

Overall labour demand is defined as the number of all job advertisements accessible to a job seeker based on residence. In building this indicator we use the sum of all job advertisements in the year of graduation and account for geographical distance, as described above, giving vacancies far away from location of residence a lower weight.

$$
O_{x j}=\sum_{b=1}^{B}\left(w_{x z} * n_{z j}\right)
$$

$\mathrm{O}_{\mathrm{x} j}$ Number of vacancies in year $\mathrm{j}$ accessible location $\mathrm{x}$ weighted with individualised geographical transition probabilities.

$\mathrm{w}_{\mathrm{xz}}$ Distance weight from location of residence $\mathrm{x}$ to location of job $\mathrm{z}$.

$\mathrm{n}_{\mathrm{zj}}$ Number of vacancies advertised in year $\mathrm{j}$ with location $\mathrm{z}$.

In addition to occupational pathways into the labour market and related job opportunities, diverse features of the training completed and individual characteristics will determine a young person's prospects for occupationally and educationally matching entry-level jobs. With this in mind we control for some factors that the literature has shown to be influential: educational achievement and competences, which are mirrored in reading literacy skills (PISA score) at lower secondary education, and the level of the lower secondary education track pursued (basic, extended or no formal requirements). As a measurement for the cognitive requirement of vocational training programmes we

\footnotetext{
${ }^{3}$ See also Buchs et al. (2015).

${ }^{4}$ For constructing occupational transition probability weights we draw on the same two-digit code that we used for constructing the dependent variable of occupational change. Geographical distance weights are constructed as follows: $w_{x z}=10 /$ driving distance in minutes

Vacancies in the district (Kanton) of residence (or with a driving. distance below $10 \mathrm{~min}$ ) are assigned a weight of 1.
} 
include the intellectual level of IVET [distinguished by six differing levels of cognitive demand, according to Stalder (2011)] and a binary variable on whether or not a vocational baccalaureate was obtained in addition to the IVET diploma. In addition, the occupational fields of IVET are distinguished into eight broad categories. Furthermore, an aggregate measure of the ratio of unskilled employment within occupational segments in the Swiss labour market, drawn from the Swiss Labour Force Survey (SLFS), characterises the share of the peripheral segment in the respective occupations. We include gender, migrant background ( $0=$ Swiss vs. $1=$ first and second generation migrants, operationalised by the country of birth and the language spoken at home), and parental socio-economic status (ISEI) as individual categories in our analysis. In addition, self-effcacy and satisfaction with the vocational training (both measured prior to labour market entry during IVET) are included, depicting non-cognitive competences and motivation respectively. Furthermore, the region of living distinguishes the German-, French- and the Italian-speaking areas of Switzerland.

\section{Methods}

We used bivariate probit regression to test the hypotheses empirically. Bivariate probit regression is an extension of the probit model (see Greene 2012) and allows for dealing with two binary dependent variables that are correlated. We assumed occupational change and unskilled employment at entry to occupational labour markets to be related transition outcomes, jointly determined by some similar factors. Some of these determinants of occupational change and unskilled employment may not be observed in survey data because the transition into the labour market is marked by a complex interplay of opportunities and motivation. Bivariate probit analysis allows us to jointly predict the two transition outcomes and thus to: (i) test for a potential correlation between the two transition outcomes, and (ii) estimate the effects of explanatory factors (such as the impact of the occupation-specific and total labour demand).

Essentially, in bivariate probit regression two separate probit models are estimated simultaneously, allowing for a correlation between the error terms of the two equations. The general specification for a bivariate probit model is as follows:

$$
\begin{aligned}
& \text { Occ }_{i}^{*}=X_{i} \beta_{1}+\varepsilon_{i 1}, \quad \text { Occ }_{i}= \begin{cases}1 & \text { if } \text { Occ }_{i}^{*}>0 \\
0, & \text { otherwise }\end{cases} \\
& \text { Inad }_{i}^{*}=X_{i} \beta_{2}+\varepsilon_{i 2}, \quad \text { Inad }_{i}= \begin{cases}1 & \text { if Inad } \\
0, & \text { otherwise }\end{cases}
\end{aligned}
$$

where $\left(\varepsilon_{i 1}, \varepsilon_{i 2}\right) \sim$ bivariate normal $[0,0,1,1, \rho]$. The binary variable $O c c_{i}$ takes on the value 1 if occupational change occurs. The binary variable Inad $_{i}$ takes on the value 1 if entrance into unskilled employment is observed. $\mathrm{Occ}_{i}{ }^{*}$ and $\mathrm{Inad}_{i}{ }_{i}^{*}$ are latent variables assumed to underlie the experience of respective transition outcomes, with $X_{i}$ as a vector of variables (including the number of job vacancies) that determine these mismatch situations. The correlation coefficient $\rho$ captures the correlation between unknown factors determining both occupational change and unskilled entry employment. If $\rho \neq 0$, then occupational change and unskilled entry employment must be regarded as interrelated transition outcomes that are determined by similar (unobserved) factors. 
Based on bivariate probit regression, we estimate and report the average marginal effects of covariates on the joint probabilities of different transition outcomes (see Christofides et al. 1997, 2000; Greene 2012). With regard to the two binary variables of interest to this study, there are four possible combinations of transition outcomes. In this respect we can investigate the effects on the according probabilities of experiencing (1) both unskilled employment and occupational change $P(O c c=1$, Inad $=1)$, (2) no mismatching $P(O c c=0$, Inad $=0)$, (3) a qualification mismatch only $P(O c c=0$, Inad $=1)$ and (4) an occupational mismatch only $P(O c c=1$, Inad $=0)$. To test Hypothesis 2 , we are most interested in the effects of occupation-specific job opportunities on the joint probability of experiencing both occupational and educational mismatch $P(O c c=1$, Inad $=1)$. In testing Hypothesis 3 , we focus on the effects of overall labour demand on the joint probability of experiencing occupational change while engaging in educationally adequate employment $P(O c c=1$, Inad $=0)$. The effects of further contextual and individual factors included in the model are only reported but not discussed in more detail as this goes beyond the scope of this study.

The analysis is employed using the software framework of Stata 13, making use of the biprobit-command. Throughout the analysis we applied customised weights, ${ }^{5}$ derived based on survey weights provided by TREE (see Sacchi 2011). These correct for both the disproportionality due to the sampling-design of PISA/TREE, as well as for panel attrition. The analysis takes into account the complex survey design of PISA/TREE for variance estimation, applying Stata SVY-commands.

\section{Results and discussion}

Based on descriptive results, we find significant differences in the ratio of unskilled young people employed in first jobs across IVET graduates who changed their occupational field of training and those who engaged in a first job within it. Of those who switched occupations, $43 \%$ are concurrently employed in unskilled entry jobs, whereas of those who found employment within their occupational field of training, only $17 \%$ are in unskilled employment (see Table 1). This descriptive result thus suggests that occupational change and unskilled entry employment among IVET graduates coincide. In the next paragraph we present the results of multivariate probit models to test this assumption further. The influence of individual job opportunities on the transition to the labour market is then discussed.

A bivariate probit model on constant terms (including no explanatory variables in the model) yields an estimate of the tetrachoric correlation, which is a correlation measure for a pair of binary variables (see Greene 2012) between the two transition outcomes. We find, as expected, occupational change upon graduation and labour market entry via unskilled employment to be significantly positively correlated (rho $=0.57$ ). Including diverse structural and individual explanatory variables (as described in the methods section of this paper and presented in Table 2), we can still find a positive and significant disturbance correlation. Therefore, common unobserved factors promote both occupational changes upon IVET graduation as well as labour market entry via unskilled

\footnotetext{
${ }^{5}$ For each respondent a customised and truncated weight was used that was based on the panel weight for the survey year of his/her labour market entry (year of first job) (for details cf. Sacchi 2011, p. 22).
} 
Table 1 Transition outcomes

\begin{tabular}{llll}
\hline Transitional outcomes & Adequate employment & Unskilled employment & Total \\
\hline Occupational change & $163(57 \%)$ & $121(43 \%)$ & $284(100 \%)$ \\
Stay within occupation & $827(83 \%)$ & $166(17 \%)$ & $993(100 \%)$ \\
\hline
\end{tabular}

Absolute numbers with weighted row percentages in brackets, design based $F(1336)=11, p<0.001$

Table 2 Average marginal effects on joint probabilities of transition outcomes

\begin{tabular}{|c|c|c|c|c|c|c|c|c|}
\hline \multirow[t]{2}{*}{ Joint probabilities } & \multicolumn{2}{|c|}{$\begin{array}{l}(\text { Occ }=1, \text { Inad }=1) \\
N=108\end{array}$} & \multicolumn{2}{|c|}{$\begin{array}{l}(\text { Occ }=0, \text { Inad }=0) \\
N=729\end{array}$} & \multicolumn{2}{|c|}{$\begin{array}{l}(\text { Occ }=0, \text { Inad }=1) \\
N=145\end{array}$} & \multicolumn{2}{|c|}{$\begin{array}{l}(\text { Occ }=1, \text { Inad }=0) \\
N=135\end{array}$} \\
\hline & AME & S.e. & AME & S.e. & AME & s.e. & AME & s.e. \\
\hline $\begin{array}{r}\text { Occ-specific job } \\
\text { opportunities }\end{array}$ & $-0.54^{* *}$ & 0.18 & $0.91^{* *}$ & 0.31 & 0.18 & 0.18 & $-0.55^{* * *}$ & 0.15 \\
\hline $\begin{array}{l}\text { Overall labour } \\
\text { demand }\end{array}$ & 0.006 & 0.007 & -0.008 & 0.014 & -0.009 & 0.007 & $0.012^{*}$ & 0.005 \\
\hline $\begin{array}{l}\text { Ratio of unskilled } \\
\text { work }\end{array}$ & $0.44^{*}$ & 0.21 & $-0.83^{*}$ & 0.40 & 0.40 & 0.31 & -0.01 & 0.23 \\
\hline Field ${ }^{\text {b. construction }}$ & 0.07 & 0.05 & $-0.17\left(^{*}\right)$ & 0.09 & 0.09 & 0.06 & 0.00 & 0.03 \\
\hline $\begin{array}{l}\text { Field }^{\text {b}} \text { : business and } \\
\text { sales }\end{array}$ & $0.17^{* * *}$ & 0.04 & $-0.29^{* * *}$ & 0.06 & 0.03 & 0.05 & $0.09^{*}$ & 0.04 \\
\hline Field ${ }^{b}$ : services & 0.07 & 0.06 & -0.14 & 0.11 & -0.01 & 0.06 & 0.08 & 0.05 \\
\hline $\begin{array}{l}\text { Field }{ }^{b} \text { : printing and } \\
\text { design }\end{array}$ & 0.01 & 0.04 & -0.03 & 0.10 & 0.01 & 0.06 & 0.00 & 0.04 \\
\hline Field ${ }^{b}$ : medical care & 0.03 & 0.05 & -0.10 & 0.10 & 0.10 & 0.07 & -0.02 & 0.03 \\
\hline $\begin{array}{l}\text { Field }{ }^{\text {b: informat. }} \\
\text { tech. }\end{array}$ & -0.04 & 0.02 & 0.07 & 0.08 & 0.02 & 0.07 & $-0.05^{*}$ & 0.02 \\
\hline $\begin{array}{l}\text { Field }{ }^{b} \text { : agricult. and } \\
\text { gardening }\end{array}$ & -0.01 & 0.03 & -0.00 & 0.09 & 0.05 & 0.06 & -0.03 & 0.03 \\
\hline Occ. baccalaureate & 0.02 & 0.03 & -0.04 & 0.05 & -0.00 & 0.03 & 0.02 & 0.03 \\
\hline Level of IVET & 0.01 & 0.01 & -0.01 & 0.02 & -0.01 & 0.01 & $0.02\left(^{*}\right)$ & 0.01 \\
\hline $\begin{array}{l}\text { Lower secondary } \\
\text { (basic) }\end{array}$ & $0.05\left(^{*}\right)$ & 0.03 & $-0.10^{*}$ & 0.05 & $0.06\left(^{*}\right)$ & 0.03 & -0.02 & 0.02 \\
\hline $\begin{array}{l}\text { Lower secondary } \\
\text { (not formal) }\end{array}$ & -0.02 & 0.04 & 0.02 & 0.09 & -0.04 & 0.03 & 0.04 & 0.07 \\
\hline Reading literacy & 0.00 & 0.00 & -0.00 & 0.00 & 0.00 & 0.00 & -0.00 & 0.00 \\
\hline Gender (male) & $0.045^{*}$ & 0.02 & $-0.08\left(^{*}\right)$ & 0.04 & -0.02 & 0.03 & $0.05^{*}$ & 0.02 \\
\hline Migrant background & 0.02 & 0.04 & -0.05 & 0.07 & 0.07 & 0.05 & -0.04 & 0.03 \\
\hline Parental ISEI & -0.00 & 0.00 & 0.00 & 0.00 & -0.00 & 0.00 & 0.00 & 0.00 \\
\hline $\begin{array}{l}\text { Satisfaction with } \\
\text { IVET }\end{array}$ & -0.01 & 0.01 & 0.02 & 0.02 & $-0.02\left(^{*}\right)$ & 0.01 & 0.01 & 0.01 \\
\hline Self-efficacy & 0.01 & 0.03 & -0.02 & 0.05 & -0.01 & 0.02 & 0.02 & 0.02 \\
\hline Regionc: French & -0.00 & 0.03 & -0.01 & 0.05 & 0.04 & 0.04 & -0.03 & 0.03 \\
\hline Regionc: Italian & 0.01 & 0.05 & -0.02 & 0.09 & -0.00 & 0.04 & 0.01 & 0.05 \\
\hline
\end{tabular}

The number of cases differs slightly from those reported in Table 1 due to list wise deletion on missing values in some explaining variables

(*) $p \leq 0.1$

* $p \leq 0.05$

** $p \leq 0.01$

*** $\mathrm{p} \leq 0.001$

a Ref.cat: lower secondary with extended requirements

b Ref. cat: field of technical occupations

c Ref.cat: German speaking region 
employment. These results are in line with Hypothesis 1. Occupational segmentation seems to hinder young graduates from accessing skilled employment outside of the occupation of their training. It seems that they cannot find an institutionalised pathway from their IVET programme to occupations outside of the occupation of their training. Instead they are likely to have to accept unskilled employment in the peripheral segment of the labour market when switching occupations shortly after graduation. Therefore, our results confirm that occupational change and unskilled entry employment may need to be viewed as related transition outcomes among IVET graduates.

At entry to an occupational labour market the number of qualified job opportunities in the occupational field of training, as we identified in our theoretical discussion, has the potential to drive both occupational and educational mismatch. Furthermore, we expect overall labour demand in the year of graduation to promote skilled employment when switching occupations. In Table 2 we present average marginal effects of occupation-specific and overall labour demand on the probabilities of different job-education mismatch situations. For ease of interpretation, the effect of occupation-specific job opportunities and of overall demand on the transition to the labour market is highlighted in Figs. 1 and 2. The following discussion focuses mainly on the joint probability of an occupational change and engaging in unskilled entry employment (column 1), as this is the mismatch outcome of most interest to this study.

The results further confirm that a small number of adequate job opportunities in IVET graduates' respective field of training at the time of graduation increases the risk of not finding a job that corresponds to training both in occupation and in the level of qualification. A high number of occupation-specific job opportunities significantly reduces young labour market entrant's risk of experiencing a transition that is both occupationally and educationally mismatched (Hypothesis 2) (see column 1 of Table 2; Fig. 1). With a focus on adequate transitions, the results are also in line with expectations. A larger number of occupation-specific job opportunities is related to a higher chance of engagement in skilled employment within the trained occupation (see column 2 of Table 2; Fig. 1). The results indicate that in situations of low occupation-specific demand, labour market entrants might be crowded out of skilled employment within their field of training by more experienced job seekers because employers can more readily choose

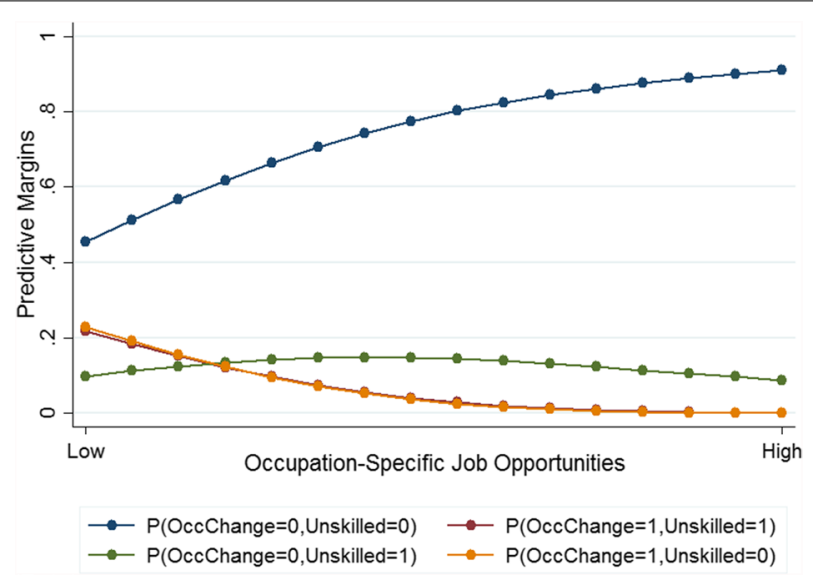

Fig. 1 Number of job opportunities in the IVET occupation and the transition to the labour market 


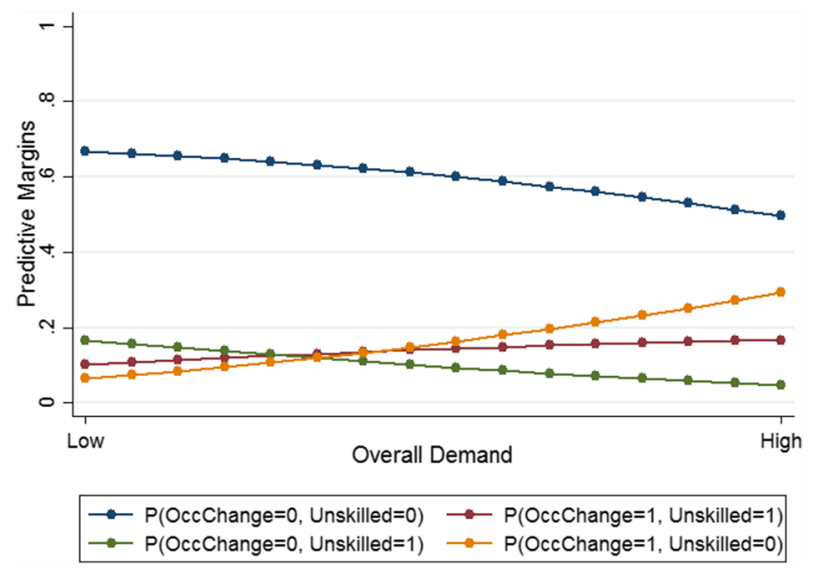

Fig. 2 Overall demand and the transition to the labour market

between applicants. To avoid unemployment, they may have to accept unskilled employment or an occupational mismatch. Further, the results suggest that fewer job vacancies in the occupational field of training generally favours occupational change among IVET graduates, also into skilled positions (see also Buchs et al. 2015). All in all, constraints occupation-specific job may be seen as an important determinant of the conjoint transition outcome of changing the occupational field and entering the labour market by accepting unskilled employment.

High overall labour demand, as proposed in Hypothesis 3, increases the chances of young graduates accessing skilled employment when leaving the occupation for which they trained. Column 4 in Table 2 shows a significant positive effect of the number of job opportunities in the overall labour market on skilled employment outside the occupational field of training. This result is in line with the expectation gained from labour queue theory that the higher the demand for specific skills, the more employers are willing to reduce their requirements regarding matching occupational certificates. When overall demand is high, young people switching occupations can thus profit because in this situation they have a higher chance of accessing skilled employment. Yet, a high overall labour demand at the time of completion of IVET does not reduce the risk of taking up employment that is marked by both an occupational change and inadequate educational requirements. Furthermore, additional analyses show that high overall demand in the labour market particularly increases the probability of changing occupations when occupation-specific job opportunities are few. ${ }^{6}$

A high number of job opportunities in the overall labour market does however not pull all IVET graduates to switching occupations to the same extend. Focusing on further structural determinants of entering the labour market via occupationally and educationally mismatched employment (column 1 , Table 2 ), we find the experiences of occupational, as well as educational mismatch after graduation, are related to the characteristics of the occupational field of training. Similar to the results presented by Eggenberger et al. (2015),

\footnotetext{
${ }^{6}$ We test this proposition by checking for differential effects of overall labour demand across varying levels of occupation-specific demand. Therefore, we include an interaction term between occupation-specific labour demand and overall labour demand in the analysis. See also Fig. 3 in the appendix.
} 
young people with training in occupational fields that impart rather broad skills, such as business and sales, have a higher chance of switching occupations than do their peers who completed training in fields that impart rather specific skills, such as technical occupations (concurring with both educationally adequate or unskilled employment outside their occupational field of training). This probably means that they can profit more readily from a high overall labour demand if they have to leave the occupation for which they trained. A higher share of unskilled work in the occupation for which the graduates trained, drives occupational change and labour market entry via unskilled employment. It seems that general employment prospects in the occupation for which they trained, and hence the attractiveness of this segment, influences the decision of young people to switch occupations.

\section{Conclusions}

In general, institutionalised pathways from IVET to work guarantee smooth transitions from school to occupational labour markets, preventing job-education. However, in the event that graduates do not find qualified job opportunities in their occupational field of training and have to change occupations at labour market entry, these pathways may prove disadvantageous for young peoples' integration into skilled employment. Highlighting the link between occupational changes and unskilled employment is crucial in order to understand processes of social stratification in occupational labour markets as unskilled employment may hamper their career prospects. The present study aims to show in how far these two transition outcomes are related and which role individual job opportunities play.

The most important insight gained from the present study is that occupational change upon graduation from IVET and unskilled entry employment, that is, employment not requiring any vocational education or other qualifying educational credentials, are interrelated transition outcomes. IVET graduates changing occupations at labour market entry thus not only risk losing occupation-specific knowledge and skills acquired during training, they may also be unable to utilise any of their educational investment as they risk entering the labour market via unskilled employment. Moreover, unskilled employment at entry to an occupational labour market may have a negative signalling effect and may prevent young people from accumulating work experience in skilled positions, both aspects likely to constrain upward mobility to skilled employment. Therefore, occupational mismatch concurring with unskilled employment may prove to be rather persistently detrimental with regards to the future labour market positioning of young adults (see e.g. Baert et al. 2013; Pollmann-Schult and Büchel 2002; Scherer 2004) and thereby severely hamper their social positioning (see e.g. Blossfeld 1985; Bukodi and Dex 2010). Our study thus contributes to a more comprehensive understanding of how institutionalised pathways into occupational labour markets may lead to unfavourable employment outcomes among IVET graduates.

This contribution is also one of the first studies to assess the role of job opportunities measured at the micro level for transitions to an occupational labour market. It sheds light on the crucial importance of qualified job opportunities in the occupation for which young IVET graduates trained as well as on overall labour demand upon completion of 
training with regards to adequate employment. In doing so, it highlights that a scarcity of vacancies in the occupational field of training drives occupational changes among IVET graduates (see also Buchs et al. 2015). As moving out of the occupational field of training often coincides with unskilled employment, few occupation-specific job opportunities thus promote a twofold job-education mismatch. Further, the present study shows that strong overall labour demand at completion of IVET enables young people to find employment in occupations for which they have no specific training, thereby also opening up the possibility of them gaining access to skilled employment. A high number of job opportunities in the overall labour market may thus be a bulwark against having to accept unskilled employment or even unemployment when demand in the occupation of training is weak. The results support the idea, taken from labour-queue theory, that a high demand in the overall labour market increases firms' readiness to employ young graduates not holding an occupation-specific certificate, whereas in situations of low demand such a certificate is a prerequisite for IVET graduates entering occupations they have not been trained for.

An important insight gained from this study is that the "exogenous" structure of available job opportunities is, besides widely discussed individual and social resources, crucial for IVET graduates' successful integration into occupational labour markets. The preeminent importance of occupation-specific job opportunities indicates that vocational training systems need to provide the occupational skills demanded by employers to prevent their graduates from having to change occupations and to thus shelter them from the risk of entering the labour market via unskilled employment. In this regard, and also in light of shifts in demand towards the tertiary level (Sacchi, Salvisberg and Buchmann 2005), pathways from IVET to higher education that enable the young to increase their negotiating power for skilled positions and professional development-also outside their fields of their first training-are highly important. This study also highlights that further research analysing entries to occupational labour markets should take the structure of available job opportunities at the micro level into account. Not depicting the demand side adequately would mean leaving out one of the main driving factors behind transitions to occupational labour markets.

Authors' contributions

$\mathrm{HB}$ and LH have worked closely together on most aspects of this manuscript concerning data preparation, analysis and writing. $\mathrm{HB}$ is mainly responsible for the preparation of data from the Swiss Job Market monitor and the elaboration of the theoretical background while LH is mainly responsible for the application of the analysis. Both authors read and approved the final manuscript.

Author details

${ }^{1}$ Institute of Sociology, University of Zürich, Andreasstrasse 15, 8050 Zurich, Switzerland. ${ }^{2}$ Social Research and Methodology Group, University of Basel, Petersgraben 9/11, 4051 Basel, Switzerland.

Acknowledgements

We are indebted to Dr. Stefan Sacchi, Dr. Emily Murphy and two anonymous reviewers for valuable critical feedback. 


\section{Competing interests}

The authors declare that they have no competing interests. The manuscript has not been submitted for publication or published elsewhere.

\section{Availability of data}

The datasets supporting the conclusions of this article are available in the FORS repository, Ref Projekt: 7154 (https:// forsbase.unil.ch/project/study-public-overview/13035/0/) and Ref Projekt: 11998 (https://forsbase.unil.ch/project/ study-public-overview/13492/0/)

\section{Funding}

We thank the Swiss National Science Foundation (SNSF) for funding.

\section{Appendix}

See Table 3 and Fig. 3.

Table 3 Sample descriptives

\begin{tabular}{|c|c|c|c|c|c|}
\hline Metric or binary characteristics & Min & Max & Mean & SD & $\mathbf{N}$ \\
\hline Occ. change & 0 & 1 & 0.31 & 0.46 & 1375 \\
\hline Inad. work & 0 & 1 & 0.25 & 0.43 & 1277 \\
\hline Job vacancies in occ. field & 0.01 & 0.77 & 0.17 & 0.14 & 1387 \\
\hline Total job vacancies & 2.48 & 18.14 & 6.77 & 3.40 & 1387 \\
\hline Ratio of unskilled work & 0.01 & 0.39 & 0.15 & 0.09 & 1387 \\
\hline Occupational baccalaureate & 0 & 1 & 0.15 & 0.36 & 1387 \\
\hline Level of IVET & 1 & 6 & 3.33 & 1.90 & 1386 \\
\hline Reading literacy & 81.39 & 741.90 & 436.24 & 116.61 & 1385 \\
\hline Gender (male) & 0 & 1 & 0.69 & 0.46 & 1387 \\
\hline Migrant background & 0 & 1 & 0.24 & 0.43 & 1335 \\
\hline Parental isei & 16 & 90 & 39.34 & 13.39 & 1337 \\
\hline Satisfaction with IVET & 1 & 7 & 5.24 & 1.16 & 1367 \\
\hline Self-efficacy & 2 & 4 & 3.01 & 0.61 & 1299 \\
\hline Categorical characteristics & \multicolumn{4}{|c|}{ Percent (\%) } & $N$ \\
\hline Field: construction & \multicolumn{4}{|c|}{16} & 103 \\
\hline Field: business and sales & \multicolumn{4}{|c|}{38} & 623 \\
\hline Field: services & \multicolumn{4}{|c|}{8} & 140 \\
\hline Field: printing and design & \multicolumn{4}{|c|}{2} & 51 \\
\hline Field: medical care & \multicolumn{4}{|c|}{4} & 82 \\
\hline Field: informat. tech. & \multicolumn{4}{|c|}{1} & 29 \\
\hline Field: agricult and gardening & \multicolumn{4}{|c|}{10} & 96 \\
\hline Field: technical occupations & \multicolumn{4}{|c|}{21} & 257 \\
\hline Lower secondary (extended) & \multicolumn{4}{|c|}{48} & 846 \\
\hline Lower secondary (basic) & \multicolumn{4}{|c|}{50} & 472 \\
\hline Lower secondary (not formal) & \multicolumn{4}{|c|}{2} & 68 \\
\hline Region: German & \multicolumn{4}{|c|}{72} & 871 \\
\hline Region: French & \multicolumn{4}{|c|}{26} & 388 \\
\hline Region: Italian & \multicolumn{4}{|c|}{2} & 128 \\
\hline
\end{tabular}

A weight was applied to derive the descriptive statistics reported 


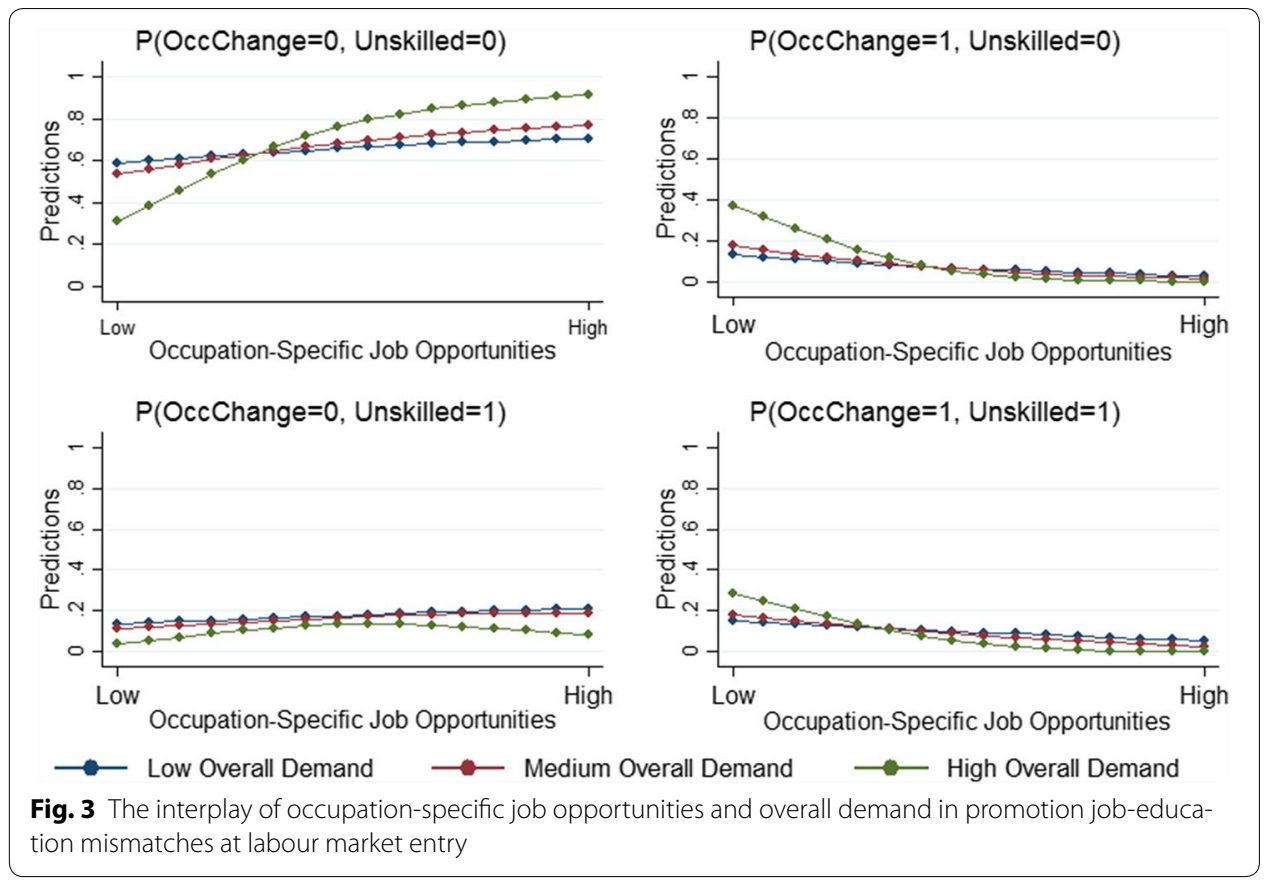

Received: 25 August 2016 Accepted: 26 November 2016

Published online: 03 December 2016

\section{References}

Baert S, Cockx B, Verhaest D (2013) Overeducation at the start of the career: stepping stone or trap? Lab Econ 25:123-140. doi:10.1016/j.labeco.2013.04.013

Blossfeld HP (1985) Berufseintritt und Berufsverlauf. Eine Kohortenanalyse über die Bedeutung des ersten Berufs in der Erwerbsbiographie. MittAB 18(2):177-197

Blossfeld HP, Mayer KU (1988) Labor market segmentation in the federal republic of germany: an empirical study of segmentation theories from a life course perspective. Eur Sociol Rev 4:123-140

Blossfeld HP, Skopek J, Triventi M, Buchholz S (2015) Gender, education and employment. an international comparison of school-to-work transitions. Edward Elgar, Cheltenham

Buchmann MC (2011) School to work transitions. In: Brown BB, Prinstein MJ (eds) Encyclopedia of adolescence, vol 2E. Elsevier, London, pp 306-313

Buchs H, Müller B (2016) L'offre d'emplois conditionne la qualité de l'intégration dans le marché du travail Suisse: Une comparaison formation duale/formation en École. Formation Empl 133:55-75

Buchs H, Mueller B, Buchmann M (2015) Qualifikationsnachfrage und Arbeitsmarkteintritt in der Schweiz. Köln Z Soziol 67(4):709-736. doi:10.1007/s11577-015-0342-5

Bukodi E, Dex S (2010) Bad start: is there a way up? gender differences in the effect of initial occupation on early career mobility in britain. Eur Sociol Rev 26:431-446

Christofides LN, Stengos T, Swidinsky R (1997) On the calculation of marginal effects in the bivariate probit model. Econ Lett 54:203-208

Christofides LN, Hardin JW, Stengos T (2000) Corrigendum to "On the calculation of marginal effects in the bivariate probit model." Econ Lett 68:339

Eggenberger C, Rinawi M, Backes-Gellner U (2015) Measuring the specificity of occupational training curricula and labor market flexibility —an economic perspective on the curriculum. Swiss Leading House WP 106, Zürich

Gangl M (2003) Returns to education in context: individual education and transition outcomes in european labour markets. In: Müller W, Gangl M (eds) Transitions from education to work in Europe. The Integration of Youth into EU Labour Markets. Oxford University Press, New York, pp 156-185

Gebel M (2010) Early career consequences of temporary employment in Germany and the UK. Work Employ Soc 24(4):641-660

Greene WH (2012) Econometric analysis, 7th edn. Pearson, Boston

lannelli C, Raffe D (2007) Vocational upper-secondary education and the transition from school. Eur Sociol Rev 23(1):49-63

Kriesi I, Buchmann M, Sacchi S (2010) Variation in job opportunities for men and women in the swiss labor market 1962-1989. Res Soc Stratif Mob 28(3):309-323

Mincer J (1974) Schooling, experience, and earnings. Columbia University Press, New York 
Mueller B, Schweri J (2015) How specific is apprenticeship training? Evidence from inter-firm and occupational mobility after graduation. Oxford Econ Papers 67(4):1057-1077. doi:10.1093/oep/gpv040

OECD (2013) Youth unemployment rate. Employment and labour markets: Key tables from OECD 10.1787/unemp-ythtable 2013-1-en

Pedulla D (2016) Penalized or protected? Gender and the consequences of nonstandard or mismatched employment histories. Am Sociol Rev 81(2):262-289. doi:10.1177/0003122416630982

Pollmann-Schult M, Büchel F (2002) Ausbildungsinadäquate Erwerbstätigkeit: Eine berufliche Sackgasse? Eine Analyse für jüngere Nicht-Akademiker in Westdeutschland. MittAB 35(3):371-384

Sacchi S (2011) Construction of TREE panel weights. Documentation for the panel waves from 2000-2010. TREE and Cue Sozialforschung, Bern

Sacchi S, Salvisberg A, Buchmann M (2005) Long-term dynamics of skill demand in Switzerland, 1950-2000. In: Kriesi HP, Farago P, Kohli M, Zarin-Nejadan M (eds) Contemporary Switzerland. Revisiting the Special Case. Palgrave Macmillan, Basingstoke, pp 105-134

Sacchi S, Kriesi I, Buchmann M (2016) Occupational mobility chains and the role of job opportunities for upward, lateral and downward mobility in Switzerland. Res Soc Stratif Mob 44:10-21

Salvisberg A, Sacchi S (2013) Labour market prospects of swiss career entrants after completion of vocational education and training. Eur Soc 16(2):255-274

Scherer S (2004) Stepping-stones or traps? the consequences of labour market entry positions on future careers in WEST Germany, Great Britain and Italy. Work Employ Soc 18:369-394

Sengenberger W (1978) Arbeitsmarktstruktur. Ansätze zu einem Modell des segmentierten Arbeitsmarkts. Campus, Frankfurt am Main

SERI (2015) Facts and figures 2015. Vocational and professional education and training in Switzerland 2015. State Secretariat for Education, Research and Innovation SERI, Biel

SKBF (2014) Swiss education report 2014. SKBF, Aarau

Stalder BE (2011) Das intellektuelle. Anforderungsniveau beruflicher Grundbildungen in der Schweiz Ratings der Jahre 1999-2005. Institut für Soziologie der Universität Basel/TREE, Basel

Stalder BE, Nägele C (2011) Vocational education and training in Switzerland: organisation, development and challenges for the future. In: Bergman MM, Hupka-Brunner S, Keller A, Meyer T, Stalder BE (eds) Transitionen im jugendalter. Ergebnisse der Schweizer Längsschnittstudie TREE, Zürich, pp 18-39

Thurow LC (1975) Generating inequality. Mechanisms of distribution in the U.S. economy. Basic books, University of California, California

TREE (2013) TREE project documentation 2000-2012. TREE, Basel

Vandenberghe V (2010) The long-term effects of recessions on youth. Reviewing the evidence. Université catholique de Louvain (UCL), Louvain-la-Neuve

Verhaest D, Van der Velden R (2012) Cross-country differences in graduate overeducation. Eur Sociol Rev 29(3):642-653

Wolter SC, Ryan P (2011) Apprenticeship. In: Hanushek EA, Machin SJ, Woessmann L (eds) Handbook of economics of education, vol 3. Elsevier, Amsterdam, pp 521-576

\section{Submit your manuscript to a SpringerOpen ${ }^{\circ}$ journal and benefit from:}

- Convenient online submission

- Rigorous peer review

- Immediate publication on acceptance

- Open access: articles freely available online

- High visibility within the field

- Retaining the copyright to your article

Submit your next manuscript at $\boldsymbol{\Delta}$ springeropen.com 